\title{
ANALISIS USAHA PENGOLAHAN IKAN ASIN DI DESA TANAH MERAH KECAMATAN TANAH MERAH
}

(Studi Kasus Usaha Pengolahan Ikan Asin Bapak Abdullah)

\author{
Gusti Ayu ${ }^{1}$ \\ ${ }^{1}$ Program StudiAgribisnisFakultasPertanian UNISI
}

Email : gustiayu10202017@gmail.com

\begin{abstract}
ABSTRAK
Penelitian ini bertujuan untuk mengetahui besarnya penerimaan, biaya, dan keuntungan pada usaha pengolahan ikan asin serta untuk menganalisis efisiensi pada usaha pengolahan ikan asin melalui studi kasus usaha ikan asin Bapak Abdullah di Desa Tanah Merah. Metode yang digunakan untuk menganalisis data dalam penelitian ini adalah dengan menggunakan alat analisis biaya, penerimaan, keuntungan serta efisiensi usaha. Penelitian ini dilakukan dengan menggunakan metode observasi dan wawancara langsung dengan responden. Hasil penelitian menunjukkan bahwa biaya tidak tetap sebesar Rp.44.254.000,00/bulan dan biaya tetap sebesar Rp.2.463.277,78/bulan. Rata - rata penerimaan yang diperoleh sebesar Rp. 46.717.277,78 per bulan, sehingga keuntungan rata-rata yang diperoleh adalah sebesar Rp. 14.202.722,22 per bulan. Dari hasil tersebut diperoleh nilai RCR sebesar 1,30 yang berarti usaha pengolahan ikan asin Bapak Abdullah di Desa Tanah Merah efesien.
\end{abstract}

Kata kunci : ikan asin, keuntungan, efisiensi

\section{ABSTRACT}

The purposes of research were to determine the net income, cost and profit and to analyze efficiency the Business Salted Fish Bapak Abdullah. The method of data analyzed are total cost, analysis of revenue, profit analysis and effIciency analysis. This research was conducted using the method of direct observation and interviews with questionnaires. The research results show that variabel cost Rp.44.254.000,00/ months and fix cost Rp.2.463.277,78/bulan, average revenue is Rp. 46.717.277,78/ months, and average net income is Rp.6.798.240,44 per months. RCR value is equal to 1,30 , which mean salted fish business is effecien.

Key word: salted fish, profit, effeciency

\section{PENDAHULUAN}

Indonesia adalah negara kepulauan terbesar di dunia karena memiliki luas laut dan jumlah pulau yang besar. Potensi tersebut menempatkan Indonesia sebagai negara yang dikaruniai sumber daya kelautan yang besar termasuk kekayaan keanekaragaman hayati dan non hayati kelautan. Untuk 
perikanan tangkap, potensi Indonesia sangat melimpah sehingga dapat diharapkan menjadi sektor unggulan perekonomian nasional. Untuk itu potensi tersebut harus dimanfaatkan secara optimal guna meningkatkan pendapatan masyarakat. Peluang pengembangan usaha perikanan Indonesia memiliki prospek yang tinggi. Potensi ekonomi sumber daya kelautan dan perikanan yang dapat dimanfaatkan untuk mendorong pertumbuhan ekonomi diperikirakan mencapai USD 82 miliar per tahun.

Kabupaten Indragiri Hilir merupakan salah satu Kabupaten yang terletak di Provinsi Riau tepatnya di pesisir laut sehingga menjadikan Kabupaten Indragiri Hilir sebagai salah satu Kabupaten yang memiliki potensi kelautan dan perikanan. Menurut data BPS Kabupaten Indragiri Hilir tahun 2017, produksi perikanan tangkap menurut Kecamatan dan Subsektornya di Kabupaten Indragiri Hilir yang paling tinggi adalah Kecamatan Tanah Merah. Usaha perikanan yang berkembang didaerah ini adalah usaha penangkapan ikan di laut, usaha pengolahan dan pengawetan.

Sebagaimana diketahui ikan merupakan produk yang sangat mudah mengalami pembusukan. Secara umum kerusakan atau pembusukan ikan dan hasil olahannya dapat digolongkan pada: 1) Kerusakan biologi, 2) Kerusakan enzimatis, 3) Kerusakan fisika, 4) Kerusakan kimiawi. Untuk menghindari pembusukan dilakukan berbagai cara salah satunya adalah melalui proses penggaraman. Ikan yang diolah dengan proses penggaraman ini dinamakan ikan asin (Adawyah, 2008).
Usaha pengolahan ikan asin Bapak Abdullah merupakan usaha agroindustri yang cukup berkembang di Desa Tanah Merah Kecamatan Tanah Merah Kabupaten Indragiri Hilir. Ikan yang di olah meliputi ikan gulama, ikan bulu ayam,ikan timah, ikan duri, ikan belukang dan ikan pelipis. Usaha tersebut berdiri sejak tahun 2004 sampai dengan sekarang dan di distribusikan ke Batam, Balai, Tembilahan, Sulawesi dan lain-lain.

Dalam pelaksanaannya, usaha pengolahan ikan asin Bapak Abdullah mengalami permasalahan yaitu tidak adanya jaminan ketersediaan bahan baku serta usaha pengolahan ikan asin yang sangat bergantung pada faktor alam berupa sinar matahari. Dengan adanya permasalahan tersebut, maka pengusaha ikan asin harus mampu menjalankan usahanya secara lebih efisien. Keadaan tersebut membuat seorang pengusaha ikan asin perlu mengetahui berapa besar biayabiaya, penerimaan dan keuntungan yang diperoleh serta berapa besar efisiensi usaha yang telah dijalankan. Hal ini agar pengusaha dapat mengambil keputusan yang tepat dalam menjalankan usahanya dan mampu terus mengembangkan usahanya tersebut. Berdasrakan uraian diatas maka penelitian ini bertujuan untuk menghitung besarnya penerimaan, biaya, dan keuntungan pada usaha pengolahan ikan asin dan menganalisis besarnya tingkat efisiensi pada usaha pengolahan ikan asin studi kasus usaha ikan asin Bapak Abdullah di Desa Tanah Merah Kecamatan Tanah Merah.

\section{TINJAUAN PUSTAKA}

1.1. Ikan Asin 
Pengolahan ikan merupakan suatu cara untuk mempertahankan agar ikan tetap dalam kondisi baik. Ikan yang sudah mati akan cepat mengalami proses pembusukan. Pencegahan proses pembusukan dapat dilakukan dengan proses pengawetan. Pengawetan ikan diartikan sebagai setiap usaha untuk mempertahankan mutu ikan selama mungkin sehingga masih dapat dimanfaatkan dalam keadaan yang baik dan layak.

Ikan asin merupakan salah satu produk pengolahan perikanan tradisional yang paling sederhana dibandingkan dengan pengolahan lainnya. Produksi ini dihasilkan dari proses pengasinan (penggaraman) dengan pengeringan. Dalam proses pengeringan, kadar air pada ikan berkurang hingga tersisa $20-35 \%$, sehingga mikro oganisme pengurai tidak berkembang dan ikan lebih awet sampai batas waktu tertentu. Industri ikan asin berkembang disekitar sentra produksi perikanan, antara lain tempat pendaratan ikan,tangkahan (tempat pendaratan ikan milik swasta), tempat pelelangan ikan dan pelabuhan perikanan (Effendi dan Oktariza, 2006). Menurut Astawan dan M. Astawan (1989), langkah penggaraman pada ikan asin pada prinispnya bersifat menarik air dari jaringan daging ikan sehingga protein daging ikan akan menggumpul dan sel daging pun mengerut.

Langkah-langkah dalam proses pembuatan ikan asin sebagai berikut:

a. Penyiangan

Ikan-ikan yang berukuran besar di buang perutnya, kadangkadang dibuang sisiknya, kemudian dibelah. Beberapa jenis ikan dipotong bagian kepalanya, misalnya ikan duri. Cara-cara penyiangan yang banyak dikerjakan di beberapa daerah kadang-kadang berlainan. Namun pada umumnya perbedaan tidaklah banyak.

b. Pencucian

Pencucian dengan air bersih dilakukan untuk menghilangkan bekas-bekas darah, sisik dan kotoran lainnya. Kadang-kadang untuk pencucian ini digunakan larutan garam ringan sebagai penggaraman awal dengan kadar garam rendah agar ikan yang ditangkap tidak membusuk ketika masih di kapal. Apabila penggaraman dikerjakan ditengah laut (dikapal-kapal penangkapan ikan), maka untuk pencucian digunakan air laut.

c. Penggaraman

Penggaraman yang masih tradisional hanya dikerjakan dengan cara menaburkan Kristal-kristal garam pada permukaan ikan atau menyikatnya dengan larutan garam atau campuran antara kristal garam dan larutan garam. Pada penggaraman yang sudah maju, digunakan alat-alat yang dapat memasukkan larutan garam ke dalam daging ikan.

d. Pengeringan dan pengepakan

Setelah penggaraman selesai dikerjakan, ikan lalu dijemur atau dikeringkan dengan cara mekanis. Pengeringan hanya bertujuan mengurangi sedikit kadar air, supaya produk ikan asin tidak nampak berair. Jadi,pengeringan tidak sampai ikan asinnya menjadi benar-benar kering. Bila pengeringan dianggap cukup, lalu dipak dan dapat dijual ke pasar-pasar.

\subsection{Biaya Produksi}

Biaya dalam pengertian ekonomi adalah semua beban yang 
harus ditanggung untuk menyediakan barang yang siap dipakai konsumen. Biaya terdiri dari beberapa unsurunsur pokok yaitu:

1. Biaya merupakan pengorbanan sumber ekonomi

2. Diukur dalam satuan uang

3. Terjadi atau secara potensial akan terjadi

4. Pengorbanan tersebut untuk tujuan tertentu (Sudarsono, dalam Pangemanan, dkk (2011)).

Biaya produksi terdiri dari biaya tetap dan biaya variabel. Biaya tetap adalah biaya yang jumlahnya tidak bergantung pada perubahan jumlah produksi, misalnya biaya penyusutan peralatan. Biaya variabel adalah biaya yang dipengaruhi oleh kapasitas produksi. Semakin besar kapasitas produksi maka semakin besar biaya yang dibutuhkan dan sebaliknya (Suryani et al, 2005).

Biaya produksi menurut Mulyadi (1995) merupakan biaya-biaya yang terjadi untuk mengolah bahan baku menjadi produk jadi yang siap untuk dijual. Biaya Produksi dapat meliputi unsur - unsur sebagai berikut :

1. Bahan baku atau bahan dasar termasuk bahan setengah jadi

2. Bahan - bahan pembantu atau penolong

3. Upah tenaga kerja

4. Penyusutan peralatan produksi

5. Uang, modal, sewa

6. Biaya penunjang seperti biaya angkut dan biaya listrik

7. Pajak

\subsection{Penerimaan}

dan Keuntungan

Menurut Soekartawi (1986), penerimaan dalam usahatani merupakan perkalian antara produksi fisik dengan harga jual atau harga produksi. Penerimaan tunai usahatani didefinisikan sebagai nilai uang yang diterima dari penjualan produk usahatani. Pengeluaran usahatani didefinisikan sebagai jumlah uang yang dibayarkan untuk pembelian barang dan jasa (sebagai input) bagi usahatani. Penerimaan tunai usahatani tidak mencakup pinjaman uang untuk keperluan usahatani. Demikian pula pengeluaran tunai usahatani tidak mencakup pengeluaran bunga pinjaman pokok. Penerimaan tunai dan pengeluaran tunai. Usahatani tidak mencakup yang berbentuk benda, jadi nilai produk usahatani yang dikonsumsi tidak dihitung sebagai penerimaan tunaiusahatani dan nilai kerja yang dibayar dengan benda tidak dihitung sebagai pengeluaran tunai usahatani.

Menurut Soekartawi (1995), penerimaan adalah perkalian antara produksi yang diperoleh dengan harga jual dan biasanya produksi berhubungan negatif dengan harga, artinya harga akan turun ketika produksi berlebihan. Semakin banyak jumlah produk yang dihasilkan maupun semakin tinggi harga per unit produksi yang bersangkutan, maka penerimaan total yang diterima produsen akan semakin besar. Sebaliknya jika produk yang dihasilkan sedikit dan harganya rendah maka penerimaan total yang diterima produsen semakin kecil (Soejarmanto dan Riswan, 1994).

Penerimaan total/ pendapatan kotor adalah jumlah seluruh penerimaan dari hasil penjualan sejumlah produk (barang yang dihasilkan). Total penerimaan juga dapat didefinisikan sebagai nilai uang yang diterima dari penjualan. Barang yang dihasil dari produksi (Q) yang dilakukan dijual dengan harga pasar yang ada (P). Hasil perkalian tersebut adalah total 
penerimaan yang diterima atau biasa disebut pendapatan kotor.

Menurut Soekartawi (1991), selisih antara penerimaan tunai usahatani dan pengeluaran tunai usahatani disebut keuntungan. Untuk menganalisis keuntungan diperlukan dua keterangan pokok keadaan pengeluaran dan penerimaan dalam jangka waktu tertentu. Tujuan analisis keuntungan adalah untuk mengggambarkan tingkat keberhasilan suatu kegiatan usaha dan keadaan yang akan datang melalui perencanaan yang dibuat.

Tingkat pendapatan rumah tangga merupakan indikator yang penting untuk mengetahui tingkat hidup rumah tangga. Umumnya pendapatan rumah tangga di pedesaan tidak berasal dari satu sumber, tetapi berasal dari dua atau lebih sumber pendapatan. Tingkat pendapatan tersebut diduga dipengaruhi oleh pemenuhan kebutuhan dasar rumah tangga pengrajin. Tingkat pendapatan yang rendah mengharuskan anggota rumah tangga untuk bekerja lebih giat untuk memenuhi kebutuhan hidupnya. Pendapatan keluarga diharapkan mencerminkan tingkat kekayaan dan besarnya modal yang dimiliki pengrajin.Semakin besar pendapatan pengolah cenderung lebih berani menanggung resiko. Pendapatan besar mencerminkan tersedianya dana yang cukup untuk usahatani selanjutnya, dan pendapatan yang rendah menyebabkan menurunnya investasi dan upaya pemupukan modal.

Sumber pendapatan rumah tangga digolongkan ke dalam dua sektor, yaitu sektor pertanian dan bukan pertanian.Sumber pendapatan dari sektor pertanian dapat dirinci lagi menjadi pendapatan dari usahatani, ternak, buruh pengrajin, menyewakan lahan dan bagi hasil.Sumber pendapatan dari sektor bukan pertanian dibedakan menjadi pendapatan dari industri rumah tangga, perdagangan, pegawai, jasa, buruh bukan pertanian serta buruh subsektor non pertanian lainnya (Sayogyo, 1997).

\subsection{Efisiensi}

Efisiensi menurut ekonomi tergantung pada harga - harga faktor produksi dan pada efisiensi teknologi (terkait dengan penggunaan masukan dalam arti fisik). Jika output yang dihasilkan sama, maka proses yang terbaik adalah yang menggunakan masukan yang paling sedikit atau dengan kata lain, proses yang secara teknis paling efisien (Lipsey dan Steiner, 1986).

Besarnya efisiensi dapat dikur menggunakan $\mathrm{R} / \mathrm{C}$ ratio. $\mathrm{R} / \mathrm{C}$ adalah singkatan dari Return Cost Ratio atau dikenal sebagai perbandingan (nisbah) antara penerimaan dan biaya.

Untuk mengetahui tingkat efisiesi usaha pengolahan dan pemasaran ikan asin, maka dalam hal ini digunakan analisis Return Cost $(\mathrm{R} / \mathrm{C})$ ratio yaitu merupakan perbandingan (ratio/nisbah) antara penerimaan (revenue) dan biaya (cost). Hasil dari perbandingan antara penerimaan dengan biaya tersebut dapat diinterpretasikan dalam melihat bahwa apakah usaha pengolahan dan pemasaran tersebut layak atau tidak.

III. METODE PENELITIAN

\subsection{Tempat dan Waktu Penelitian}

Penelitian ini dilaksanakan selama 3 bulan yaitu pada bulan Mei 
sampai dengan bulan Juli 2017. Lokasi penelitian di Usaha Pengolahan Ikan Asin Bapak Abdullah di Desa Tanah Merah Kecamatan Tanah Merah Kabupaten Inhil. Lokasi dipilih karena usaha Pengolahan Ikan Asin Bapak Abdullah di Desa Tanah Merah Kecamatan Tanah Merah memiliki produksi ikan asin yang besar dan cukup berkembang di wilayah tersebut.

\subsection{Jenis dan Sumber Data}

Data yang digunakan pada penelitian ini adalah data primer dan data sekunder. Data Primer di peroleh dengan cara melakukan wawancara kepada Usaha Pengolahan Ikan Asin Bapak Abdullah di Desa Tanah Merah Kecamatan Tanah Merah dengan panduan pertanyaan yang sudah disiapkan, biasanya disebut dengan kuisioner. Data Sekunder diperoleh dari studi literatur yang relevan dengan penelitian ini seperti buku, skripsi, jurnal, internet, dan sebagainya.

\subsection{Metode Analisis Data}

\subsubsection{Biaya Produksi}

Biaya produksi yang dikeluarkan yaitu biaya tetap (FC) dan biaya variabel (VC). Untuk mengetahui total biaya produksi secara matematis dirumuskan sebagai berikut :

Keterangan :

$$
\mathrm{TC}=\mathrm{FC}+\mathrm{VC}
$$

$\mathrm{TC}=$ Total Cost (Rp/Bulan)

$\mathrm{FC}=$ Fix Cost $(\mathrm{Rp} /$ Bulan $)$

$\mathrm{VC}=$ Variabel Cost $(\mathrm{Rp} /$ bulan $)$

Pendekatan biaya yang

dilakukan selama satu kali produksi dalam sebulan adalah dengan mengakumulasikan pengeluaran selama satu kali produksi selama 30 hari. Asumsinya adalah biaya yang dikeluarkan selama satu kali produksi selalu sama selama satu bulan.

\subsubsection{Penyusutan}

Untuk menghitung biaya penyusutan alat dalam usaha tersebut dihitung dengan metode garis lurus menurut sinuraya (1985). Dengan rumus sebagai berikut:

$$
D=\frac{\mathrm{C}-\mathrm{SV}}{\mathrm{UL}}
$$

Keterangan :

$$
\begin{aligned}
\mathrm{D}= & \text { Nilai penyusutan alat } \\
& (\mathrm{Rp} / \mathrm{unit} / \mathrm{Tahun}) \\
\mathrm{C}= & \text { Harga beli alat }(\mathrm{Rp}) \\
\mathrm{SV}= & \text { Nilai sisa alat ( } 20 \% \text { dari } \\
& \text { nilai beli) } \\
\mathrm{UL}= & \text { Masa pakai alat (Tahun) }
\end{aligned}
$$

\subsubsection{Penerimaan}

Penerimaan usaha agroindustri adalah perkalian antara jumlah produksi yang diperoleh dengan harga yang berlaku dipasar (Soekartawi, 1998). Jadi, penerimaan yang didapat pengusaha ikan asin adalah merupakan perkalian antara jumlah produksi ikan asin dikali dengan harga yang berlaku dipasaran. Secara matematis rumusnya adalah sebagai berikut:

$$
\mathrm{TR}=\mathrm{Q} \times \mathrm{P}
$$

Keterangan :

$\mathrm{TR}=$ Total Revenue (Rp/Bulan)

$\mathrm{Q}=$ Quantity (Kg/Bulan)

$\mathrm{P}=$ Price $(\mathrm{Rp} / \mathrm{Kg})$

Dengan rumus diatas maka hasil dari penjualan ikan asin yang didapat merupakan fungsi dari jumlah produksi ikan asin yang terjual dengan harga yang berlaku dipasar. Pendekatan yang dilakukan dalam penelitian ini adalah dengan cara melakukan wawancara selama 2-3 kali dalam seminggu. Asumsinya adalah pendapatan selama 2-3 kali 
wawancara diakumulasikan dalam 30 hari kerja atau sebulan kerja.

\subsubsection{Keuntungan}

Keuntungan adalah selisih penerimaan atas beban sehubungan dengan usaha untuk memperoleh pendapatan tersebut selama periode tertentu. Dapat ditulis dengan rumus sebagai berikut:

Keterangan:

$$
\pi=\mathrm{TR}-\mathrm{TC}
$$

$$
\Pi=\text { Pendapatan Bersih (Rp/Bulan) }
$$

$\mathrm{TR}=$ Total Revenue (penerimaan usaha) (Rp/Bulan)

$\mathrm{TC}=$ Total Cost (Biaya usaha)

(Rp/Bulan), (Soemarso,2004)

\subsubsection{Pendapatan Kerja Keluarga}

Menurut Hernanto (1991), untuk menghitung pendapatan keluarga digunakan rumus sebagai berikut :

$$
\mathrm{PKK}=\pi+\mathrm{TKDK}+\mathrm{D}
$$

Keterangan :

$$
\begin{aligned}
\text { PKK }= & \text { Pendapatan kerja keluarga } \\
& (\text { Rp/bulan }) \\
\pi & =\text { Keuntungan (Rp/Bulan) } \\
\pi \text { TKDK }= & \text { Upah tenaga kerja dalam } \\
& \text { keluarga } \\
\mathrm{D} \quad & \text { Penyusutan Alat }
\end{aligned}
$$

\subsubsection{Efisiensi}

Menurut Soekartawi (2002), analisis Return Cost (R/C) ratio merupakan perbandingan (ratio atau nisbah) antara penerimaan (revenue) dan biaya (cost) yang dikeluarkan dalam satu kali produksi. Untuk mengetahui efisiensi, maka rumus yang dipakai yaitu:

$$
\mathrm{R} / \mathrm{C}=\mathrm{TR} / \mathrm{TC}
$$

Keterangan :

$\mathrm{R}=$ Penerimaan total usaha dagang (Rp/Bulan)

$\mathrm{C}=$ Total biaya yang dikeluarkan (Rp/Bulan)
Kriteria yang digunakan dalam penilaian efisiensi usaha adalah :

1. R/C Ratio > 1, Usaha pengolahan ikan asin dinyatakan layak.

2. $\mathrm{R} / \mathrm{C}$ Ratio $=1$, Usaha pengolahan ikan asin dinyatakan berada pada titik impas.

3. R/C Ratio < 1, Usaha pengolahan ikan asin tidak layak.

\section{HASIL DAN PEMBAHASAN \\ 4.1. Profil Usaha}

Usaha pengolahan ikan asin Bapak Abdullah di Desa Tanah Merah Kecamatan Tanah Merah telah berkembang sejak lama berdiri sejak tahun 2004 sampai dengan sekarang dan di lakukan secara turun menurun, sehingga umumnya sudah menguasai keterampilan dan pengetahuan pengolahannya. Pengusaha ikan asin tidak sulit untuk mendapatkan bahan baku pengolahan berupa ikan segar, pengusaha tempat tinggal tersebut sekaligus tempat pengolahan ikan berada pada radius jarak yang sangat dekat dengan tempat pendaratan ikan segar.

Kegiatan yang dilakukan Oleh Bapak Abdullah adalah memproduksi 6 jenis ikan segar yang di jadikan ikan asin.Yaitu ikan gulama, ikan bulu ayam, ikan pelipis, ikan timah, ikan belukang, dan ikan duri. Bapak Abdullah memiliki 1 karyawan dari tenaga kerja luar keluarga, sedangkan tenaga kerja dari dalam keluarga berjumlah 2 orang.

\subsection{Teknik Pengolahan Ikan} Asin

Kegiatan produksi usaha pengolahan ikan asin Bapak Abdullah di Tanah Merah merupakan kegiatan usaha yang di lakukan setiap hari. Bahan baku utama dalam usaha pengolahan ikan asin adalah 
ikan segar yang di peroleh dengan cara membeli dari nelayan yang langsung di antarkan ke tempat produksi. Jenis ikan yang di gunakan antara lain yaitu ikan gulama, ikan bulu ayam, ikan pelipis, ikan timah, ikan belukang dan ikan duri. Bahan baku yang di gunakan harus berupa ikan segar karena hal ini akan mempengaruhi kualitas produksi ikan asin. Langkah-langkah dalam proses produksi ikan asin dapat di jabarkan sebagai berikut:

1. Ikan segar yang telah di beli kemudian di belah, di bersihkan isi perutnya. Akan tetapi, ada juga jenis ikan yang tidak perlu di belah seperti ikan bulu ayam yang berukuran kecil. Proses pembelahan ikan sangat memerlukan keterampilan agar di peroleh bentuk ikan asin yang baik dan menarik.

2. Ikan yang telah di belah kemudian dicuci dengan air bersih untuk menghilangkan sisa sisa isi perut atau kotoran lainnya.

3. Proses selanjutnya adalah penggaraman. Ikan di garami dan di rendam dalam bak rendam selama kurang lebih 3 hari. Jumlah garam yang di gunakan adalah sepertiga dari berat ikan. Pada saat perendaman sebaiknya ikan di tata rapi agar ikan yang di belah tidak kembali menutup.

4. Setelah kurang lebih 3 hari ikan di rendam, ikan di cuci kembali dengan air bersih agar tidak ada sisa-sisa garam yang menempel pada ikan. Pencucian di lakukan dengan cara di sikat dan di bilas dengan air. Perlakuan ini di lakukan kurang lebih selama tiga kali berturut-turut karena di harapkan ikan benar-benar telah bersih.

5. Ikan yang telah bersih di cuci, kemudian di tata rapi di atas jaring, lalu di jemur selama 1-2 hari. Ikan segar menjadi ikan asin perbandingannya1:3. Jika ikan asin telah kering, ikan asin dapat di kemas agar dapat di jual.

\subsection{Faktor Produksi \\ 4.3.1 Tempat Usaha}

Dalam menjalankan suatu usaha tentunya harus ada tempat agar usaha yang dilakukan dapat berjalan. Tempat usaha pengolahan ikan asin Pak Baduk menggunakan kios. Ukuran kios usaha pengolahan ikan asin yaitu seluas 3 meter panjangx 3 meter lebar dan untuk penjemuran ikan asin luasnya berukuran 4 meter panjangx 6 meter lebar.

\subsubsection{Modal}

Setiap usaha tentu membutuhkan modal untuk membiayai kegiatan operasional usaha sehari - hari baik untuk investasi maupun keperluan lainnya. Besarnya modal diperlukan akan berbeda sesuai dengan besar kecilnya skala usaha. Menurut Heranto (1989) modal merupakan unsur pokok dalam suatu usaha yang digunakan untuk merubah pendapatan, modal usaha diklarifikasikan sebagai kekayaan utama baik dalam bentuk uang maupun barang yang digunakan untuk menghasilkan sesuatu secara langsung maupun tidak langsung dalam proses produksi. Modal pada usaha pengolahan ikan asin antara lain untuk keperluan bahan baku, pengemasan, dan alat produksi.

Bahan baku merupakan bahan mentah yang menjadi dasar 
pembuatan suatu produk yang mana bahan tersebut dapat diolah melalui proses tertentu untuk dijadikan wujud yang lain. Bahan baku dari ikan asin adalah ikan segar, dimana ikan segar itu akan di siang terlebih dahulu kemudian di bersihkan dengan air lalu di rendaman dengaan air garam kemudian di jemur sampai kering sehingga menghasilkan ikan asin .

Peralatan merupakan alat alat yang digunakan dalam melakukan proses produksi. Pada proses pengolahan ikan asin alat produksi yang digunakan yaitu pisau, keranjang, terpal, ember, bak rendam, drum plastik, batu asah, jaring dan timbangan.

\subsubsection{Tenaga Kerja}

Tenaga kerja adalah semua orang yang bersedia untuk sanggup bekerja (Sumarsono, 2009). Artinya bahwa semua orang yang melakukan kegiatan pekerjaan untuk diri sendiri atau orang lain tanpa menerima upah atau mereka yang sanggup bekerja. Pada usaha pengolahan ikan asin Bapak Abdullah di Desa Tanah Merah, sebagian besar tenaga kerja berasal dari tenaga kerja dalam keluarga dan ada juga tenaga kerja yang berasal dari luar keluarga. Tenaga kerja luar keluarga di beri upah sesuai dengan pekerjaan yang telah dilakukan.

\subsection{Analisis Usaha Pengolahan Ikan Asin}

\subsubsection{Biaya Produksi}

Biaya produksi merupakan biaya yang dikeluarkan oleh pengusaha ikan asin selama melakukan kegiatan usahanya dimulai dari proses produksi hingga menghasilkan produk, yang meliputi biaya tetap dan biaya tidak tetap. Menurut Bambang (2006), biaya tetap adalah biaya yang relatif tetap jumlahnya, dan terus dikeluarkan walaupun produksi yang diperoleh banyak atau sedikit sedangkan biaya tidak tetap adalah biaya yang besar kecilnya dipengaruhi oleh produksi yang diperoleh.Rincian biaya produksi yang dikeluarkan dalam usaha pengolahan ikan asin Bapak Abdullah dapat dilihat pada Tabel 1 .

Berdasarkan Tabel 1, biaya variabel dalam usaha pengolahan ikan asin terdiri dari biaya bahan baku, garam, air, biaya pengemasan dan listrik. Biaya bahan baku sebesar Rp.41.430.000,00/bulan. Bahan baku adalah ikan segar, meliputi ikan gulama Rp. 15.000.000,00/bulan; ikan bulu ayam Rp. $8.100 .000,00 /$ bulan; ikan pelipis $\mathrm{Rp}$. $8.100 .000,00 /$ bulan; ikan timah Rp. 4.830.000,00/bulan; ikan belukang Rp. 3.000.000,00/bulan; dan ikan duri Rp. 2.400.000,00/bulan. Garam Rp. 1.500.000,00/bulan dan air Rp. $300.000,00 /$ bulan. Biaya pengemasan berjumlah Rp. 974.000,00/bulan yang terdiri dari karung sebesar Rp.240.000,00/bulan, asoy sebsar Rp. 120.000,00/bulan, kotak sebesar Rp.600.000,00/bulan dan solasi sebesar Rp.14.000,00/bulan. Biaya listrik sebesar Rp. 50.000,00/bulan. Maka dari itu dapat diketahui biaya tidak tetap sebesar Rp. 44.254.000,00 perbulan.

Kontribusi terbesar pada biaya tidak tetap adalah bahan baku. Hal ini senada dengan penelitian yang dilakukan Putriana (2014), bahwa kontribusi terbesar pada biaya variabel adalah biaya bahan baku. 
Tabel 1. Analisis Biaya Produksi Usaha Pengolahan IkanAsin Per Bulan

\begin{tabular}{|c|c|c|c|c|c|}
\hline No & Biaya & Satuan & Volume & Harga (Rp) & Jumlah (Rp) \\
\hline \multirow[t]{11}{*}{1.} & Biaya Tidak Tetap & & & & \\
\hline & a. Ikan Segar & $\mathrm{Kg}$ & 5070 & $45.000,00$ & $41.430 .000,00$ \\
\hline & b. Garam & $\mathrm{Kg}$ & 15 & $100.000,00$ & $1.500 .000,00$ \\
\hline & c. Air & & & $10.000,00$ & $300.000,00$ \\
\hline & d. Biaya Pengemasan & & & & \\
\hline & - $\quad$ Karung & Buah & 80 & $3.000,00$ & $240.000,00$ \\
\hline & - Asoy & Bungkus & 12 & $10.000,00$ & $120.000,00$ \\
\hline & - Kotak & Buah & 120 & $5.000,00$ & $600.000,00$ \\
\hline & - Solasi & Buah & 2 & $7.000,00$ & $14.000,00$ \\
\hline & e. Listrik & & & & $50.000,00$ \\
\hline & Jumlah & & & & $44.254 .000,00$ \\
\hline \multirow[t]{6}{*}{2.} & Biaya Tetap & & & & \\
\hline & a. Tenaga Kerja & & & & $2.400 .000,00$ \\
\hline & b. Penyusutan Alat & & & & $63.277,78$ \\
\hline & c. Tempat & & & & $41.666,67$ \\
\hline & Jumlah & & & & $2.463 .277,78$ \\
\hline & Total & & & & $46.717 .277,88$ \\
\hline
\end{tabular}

Sumber : Data primer diolah, 2017

Pada Tabel 1 menunjukan bahwa biaya tetap terdiri dari biaya tenaga kerja sebesar Rp. 2.400.000,00/bulan, biaya penyusutan peralatan sebesar Rp.63.277,78/bulan dan biaya penyusutan tempat $\mathrm{Rp}$. 41.666,67/bulan, sehingga dapat diketahui biaya tetap sebesar Rp.2.463.277,78/bulan. Biaya penyusutan ini dihitung dari masing - masing peralatan yang ditentukan oleh banyaknya masing - masing alat yang digunakan dan umur ekonomisnya. Biaya penyusutan yang dimaksud disini adalah penyusutan alat-alat yang digunakan dalam pengolahan ikan asin, terdiri dari pisau, keranjang, terpal, ember, bak rendam, drum plastik, batu asah ,jaring dan timbangan. Biaya penyusutan yang dihitung pada usaha ini dihitung dalam periode per bulan. Kontribusi terbesar pada biaya tetap adalah biaya tenaga kerja. Hal ini senada dengan penelitian yang dilakukan Mega (2011), bahwa kontribusi terbesar pada biaya tetap adalah biaya tenaga kerja.

Menurut Soekartawi (1995), total biaya adalah keseluruhan biaya tetap ditambah dengan biaya tidak tetap. Biaya total merupakan biaya yang dikeluarkan pengusaha ikan asin secara keseluruhan. Total biaya usaha pengolahan ikan asin di daerah penelitian adalah rata-rata sebesar Rp. 46.702.000,00 per bulan, dimana jumlah biaya tetap rata-rata sebesar Rp. 2.463.277,78 dan biaya tidak tetap sebesar Rp. 44.254.000,00 per bulan. Dapat disimpulkan bahwa 
biaya yang berkontribusi besar adalah biaya tidak tetap.

\subsubsection{Penerimaan}

Penerimaan

usaha agroindustri adalah perkalian antara jumlah produksi yang diperoleh dengan harga yang berlaku dipasar (Soekartawi, 1998). Penerimaan yang diterima oleh pedagang adalah perkalian antara jumlah produksi ikan asin yang dihasilkan dengan harga ikan asin yang telah ditetapkan. Penerimaan usaha pengolahan Ikan Asin Bapak Abdullah di Desa Tanah Merah yang tersaji pada Tabel 2.

Tabel 2. Penerimaan Usaha Pengolahan Ikan Asin Bapak Abdullah di Desa Tanah Merah Per Bulan

\begin{tabular}{llrrr}
\hline No. & \multicolumn{1}{c}{ Produksi } & $\begin{array}{c}\text { Jumlah } \\
\text { Produksi }\end{array}$ & Harga (Rp) & \multirow{2}{*}{ Jumlah (Rp) } \\
\hline 1. & Ikan Asin Gulama & 500 & $40.000,00$ & $20.000 .000,00$ \\
2. & Ikan Asin Bulu Ayam & 300 & $37.000,00$ & $11.100 .000,00$ \\
3. & Ikan Asin Pelipis & 300 & $36.000,00$ & $10.800 .000,00$ \\
4. & Ikan Asin Timah & 230 & $34.000,00$ & $7.820 .000,00$ \\
5. & Ikan Asin Belukang & 200 & $32.000,00$ & $6.400 .000,00$ \\
6. & Ikan Asin Duri & 160 & $30.000,00$ & $4.800 .000,00$ \\
\hline \multicolumn{4}{c}{ Total Penerimaan } & $60.920 .000,00$ \\
\hline
\end{tabular}

Sumber : Data primer diolah, 2017

Tabel 2 menunjukan bahwa penerimaan yang diperoleh yaitu sebesar Rp.60.920.000,00 per bulan. Penerimaan diperoleh dari harga ikan asin gulama Rp. 40.000,00perbulan dikalikan dengan jumlah produksi ikan asin gulama yaitu 360/ $\mathrm{kg}$ perbulan, ikan asin bulu ayam Rp.37.000,00 dikalikan dengan jumlah ikan asin bulu ayam $3300 / \mathrm{kg}$ perbulannya, ikan asin pelipis Rp.36.000,00 per bulan dikalikan dengan jumlah ikan asin pelipis $270 / \mathrm{kg}$ perbulan, ikan asin timah Rp. 340.000,00 perbulan dikalikan dengan jumlah ikan asin timah $210 / \mathrm{kg}$ perbulan, ikan asin belukang Rp.32.000,00 perbulan dikalikan dengan jumlah ikan asin belukang 210/kg perbulan dan ikan asin duri Rp.30.000,00 perbulan dikalikan dengan jumlah ikan asin duri 30/kg. Pada penelitian Mega (2011), penerimaan yang diperoleh sebesar

Rp.33.216.666,67, sedangkan penerimaan yang diperoleh usaha ikan asin Bapak Abdullahlebih besar yakni sebesar Rp. 60.920.000,00/bulan, hal ini dikarenakan jumlah bahan baku ikan segar yang diolah lebih besar.

\subsubsection{Keuntungan}

Komposisi penerimaan, keuntungan dan efisiensi usaha pengolahan ikan asin Bapak Abdullah di Desa Tanah Merah yang tersaji pada Tabel 3. Keuntungan yang diperoleh usaha pengolahan ikan asin Bapak Abdullah merupakan selisih antara total penerimaan dengan total biaya yang dikeluarkan. Keuntungan yang diperoleh sebesar Rp. 14.218.000,00 per bulan. Menurut Hernanto (1998), berhasil tidaknya usaha dapat dilihat dari besarnya pendapatan yang diperoleh dalam mengelola suatu usaha. Bagi pengusaha analisis ini membantu mereka dalam mengukur apakah 
kegiatan usaha mereka pada saat ini berhasil atau tidak. Pada penelitian Zaenuri (2004), keuntungan yang diperoleh sebesar Rp. 13.778.588,47/bulan, sedangkan keuntungan yang diperoleh usaha ikan asin Bapak Abdullah lebih besar yakni sebesar Rp. 14.218.000,00/bulan.

Tabel 3. Komposisi penerimaan, keuntungan dan efisiensi usaha pengolahan Ikan Asin Bapak Abdullah di Desa Tanah Merah Per Bulan

\begin{tabular}{llr}
\hline No. & \multicolumn{1}{c}{ Uraian } & \multicolumn{1}{c}{ Jumlah (Rp) } \\
\hline 1. & Total Biaya & $46.702 .000,00$ \\
2. & Penerimaan & $60.920 .00,000$ \\
3. & Keuntungan & $14.218 .000,00$ \\
4. & Pendapatan Kerja Dalam Keluarga & $1.800 .000,00$ \\
\hline
\end{tabular}

Sumber : Data primer diolah, 2017

\subsubsection{Pendapatan Kerja dalam Keluarga}

Pendapatan kerja keluarga merupakan imbalan terhadap bunga harta sendiri, upah tenaga kerja keluarga, dan besarnya penghasilan yang di peroleh. Pada tabel 3 dapat dilihat bahwa jumlah pendapatan kerja dalam keluarga rata- rata sebesar Rp. 1.800.000,00per bulan. Pendapatan kerja keluarga diperoleh dari pendapatan bersih ditambah dengan upah tenaga kerja dalam keluarga dan penyusutan alat. Besarnya pendapatan tenaga kerja dalam keluarga pada usaha pengolahan ikan asin dikarenakan banyaknya jumlah curahan tenaga kerja dalam keluarga yang digunakan pada usaha ini. Menurut Tohir (1983), keberhasilan atau kesuksesan usaha dapat dilihat daru sudut ekonomi yaitu besarnya penghasilan atau pendapatan kerja keluarga.

\subsubsection{Efisiensi}

Efisiensi usaha adalah gambaran layak tidaknya usaha tersebut dilakukan atau diusahakan. Menurut Soekartawi (2002), analisis Return Cost $(\mathrm{R} / \mathrm{C})$ ratio merupakan perbandingan (ratio atau nisbah) antara penerimaan (revenue) dan biaya (cost). yang dikeluarkan dalam satu kali produksi. Analisis efisiensi usaha pengolahan ikan asin Bapak Abdullah tersaji pada tabel 4.

Tabel 4. Analisis efesiensi Usaha Pengolahan Ikan Asin

\begin{tabular}{|c|c|c|}
\hline No. & Uraian & Rata-rata/Produksi \\
\hline 1 & Total Penerimaan & $60,920,000,00$ \\
\hline 2 & Total Biaya & $46,717,277,78$ \\
\hline
\end{tabular}

Sumber : data primer diolah tahun 2017

Dari tabel 4 dapat dilihat bahwa usaha pengolahan ikan asin di daerah penelitian layak diusahakan, hal ini dapat dilihat dari besarnya $\mathrm{R} / \mathrm{C}$ yang diperoleh yaitu sebesar 1,30 yang berarti bahwa setiap Rp. 1 biaya yang dikeluarkan untuk usaha pengolahan ikan asin akan menghasilkan pendapatan kotor atau penerimaan sebesar Rp. 1,30 dan pendapatan bersih atau keuntungan sebesar Rp. 0,30.Hal ini senada 
dengan penelitian yang dilakukan oleh Zainuri (2004), nilai RCR yang diperoleh adalah sebesar 1,71 yang

\section{V.KESIMPULAN DAN SARAN}

\subsection{Kesimpulan}

1. Rata-rata penerimaan yang diperoleh sebesar Rp. 60.920.000,00 per bulan, sedangkan rata-rata total biaya yang dikeluarkan adalah sebesar Rp. 46.702.000,00 per bulan sehingga diperoleh keuntungan rata-rata sebesar Rp.14.218.000,00 per bulan.

2. Nilai efisiensi atau $\mathrm{R} / \mathrm{C}$ yang diperoleh adalah sebesar 1,30 yang berarti bahwa setiap Rp. 1 biaya yang dikeluarkan untuk usaha pengolahan ikan asin akan menghasilkan pendapatan kotor atau penerimaan sebesar Rp. 1,30 dan pendapatan bersih atau keuntungan sebesar Rp. 0,30. Hal ini menunjukan bahwa usaha pengolahan ikan asin Bapak

\section{DAFTAR PUSTAKA}

Adawyah, R., 2008. Pengolahan dan Pengawetan Ikan.PT. Bumi Aksara. Jakarta.

Astawan, M.W, dan Astawan,M.1989. Teknologi Pengolahan Pangan Hewani Tepat Guna Akademika Pressindo: Jakarta.

Badan Pusat Statistik. 2014. Inhil Dalam Angka. Tanah Merah.

Bambang Prasetyo. 2006. Metode Penelitian Kuantitatif : Teori dan Aplilasi. Raja Grafindo Persada : Jakarta.

Effendi dan W Oktariza,2006. Manajemen Agribisnis Perikanan. Jakarta. berarti usaha pengolahan ikan asin menguntungkan.

Abdullah di Desa Tanah Merah efisien atau layak diusahakan.

\subsection{Saran}

1. Hendaknya dapat memperkecil risiko dengan membuat olahan yang terbuat dari ikan asin yang mengalami kerusakan seperti membuat olahan abon ikan asin atau olahan lainnya, sehingga ikan asin yang mengalami kerusakaan dapat dijual kembali.

2. Di harapkan kepada pemerintah untuk memberikan perhatian penyedian bantuan modal atau pembinaan terhadap pengusaha dan masyarakat sekitar, sehingga pengusaha dapat meningkatkan pendapatannya.

Hernanto, F. 1991. Ilmu Usahatani. Penebar Swadaya. Jakarta.

Hernanto, F. 1989. Ilmu Usaha Tani. PT. Penebar Swadaya. Jakarta.

Lipsey et al, 1990. Pengantar Ilmu Ekonomi. Rineka Cipta. Jakarta.

Mega, K. 2011. Analisis Usaha Pengolahan Ikan Asin di Kabupaten Cilacap. Universitas Sebelas Maret. Surakarta.

Mulyadi, 1995. Akuntan Biaya, Edisi kelima, Yogyakarta.

R. Putriana, 2014. Analisis Usaha Pengolahan Ikan Asin di Kecamatan Juwana Kabupaten Pati. Universitas Pendidikan Indonesia. 
Sayogyo,T.1997. Garis Kemiskinan dan Kebutuhan Minimum Pangan. LPSB-IOB.Bogor.

Soedjarwanto dan Riswan 1994. Penyerapan Tenaga Kerja Pada Industri Batu Batu di Kabupaten Dati II Banyumas. Skripsi S1 Fakultas Ekonomi UNSOED. Purwokerto.

Soemarso S.R,2004, Akutansi Suatu Pengantar, Edisi Lima, Selemba Empat, Jakarta.

Soekartawi, dkk. (1986). Ilmu Usahatani dan

PenelitianUntuk

Pengembangan Petani Kecil. Jakarta:

Universitas Indonesia. (1991). Agribisnis Teori dan Aplikasinya. Jakarta: Rajawali Press. -1995,

Pembangunan Pertanian. Jakarta, Raja Grafindo Persada. (a). 1998

Analisis

Usahatani UI. Press Jakarta.

2002. Prinsip Dasar

Ekonomi Pertanian: Teori

Dana Aplikasinya. Raja Grafindo Persada, Jakarta. 2006. Analisis Usahatani. UI Press. Jakarta.

Sumarsono, sonny.2009. Ekonomi. Sumber Daya Manusia Teori dan Kebijakan Publik. Jogyakarta: Graha Ilmu.

Sugiyono.2013. Metode Penelitian

Kuantitatif Kualitatif dan

R\&D. CV Alfabeta. Bandung.

Zaenuri,2004. Analisis Usaha Pengolaha Ikan Asin di Kota Pekalongan. Skripsi S1 Fakultas Pertanian UNS. Surakarta. 